Available online at: http://journal.unj.ac.id

Jurnal

Pensil

Pendidikan Teknik Sipil

Journal homepage: $\underline{\text { http://journal.unj.ac.id/unj/index.php/ipensil/index }}$

\title{
IMPLEMENTASI PEMBELAJARAN KEWIRAUSAHAAN SMK BIDANG KEAHLIAN TEKNIK KONSTRUKSI DAN PROPERTI DI YOGYAKARTA
}

\section{IMPLEMENTATION OF ENTREPRENEURSHIP LEARNING VOCATIONAL SCHOOL IN CONSTRUCTION AND PROPERTY ENGINEERING IN YOGYAKARTA}

\author{
Wisnu Rachmad Pribadi', Abdul Malik', Suparman ${ }^{3}$ \\ ${ }^{1,2,3}$ Universitas Negeri Yogyakarta, Jl. Colombo Yogyakarta No. 1, DI Yogyakarta, 55281, \\ Indonesia \\ 1wisnurachmadprihadi@,uny.ac.id
}

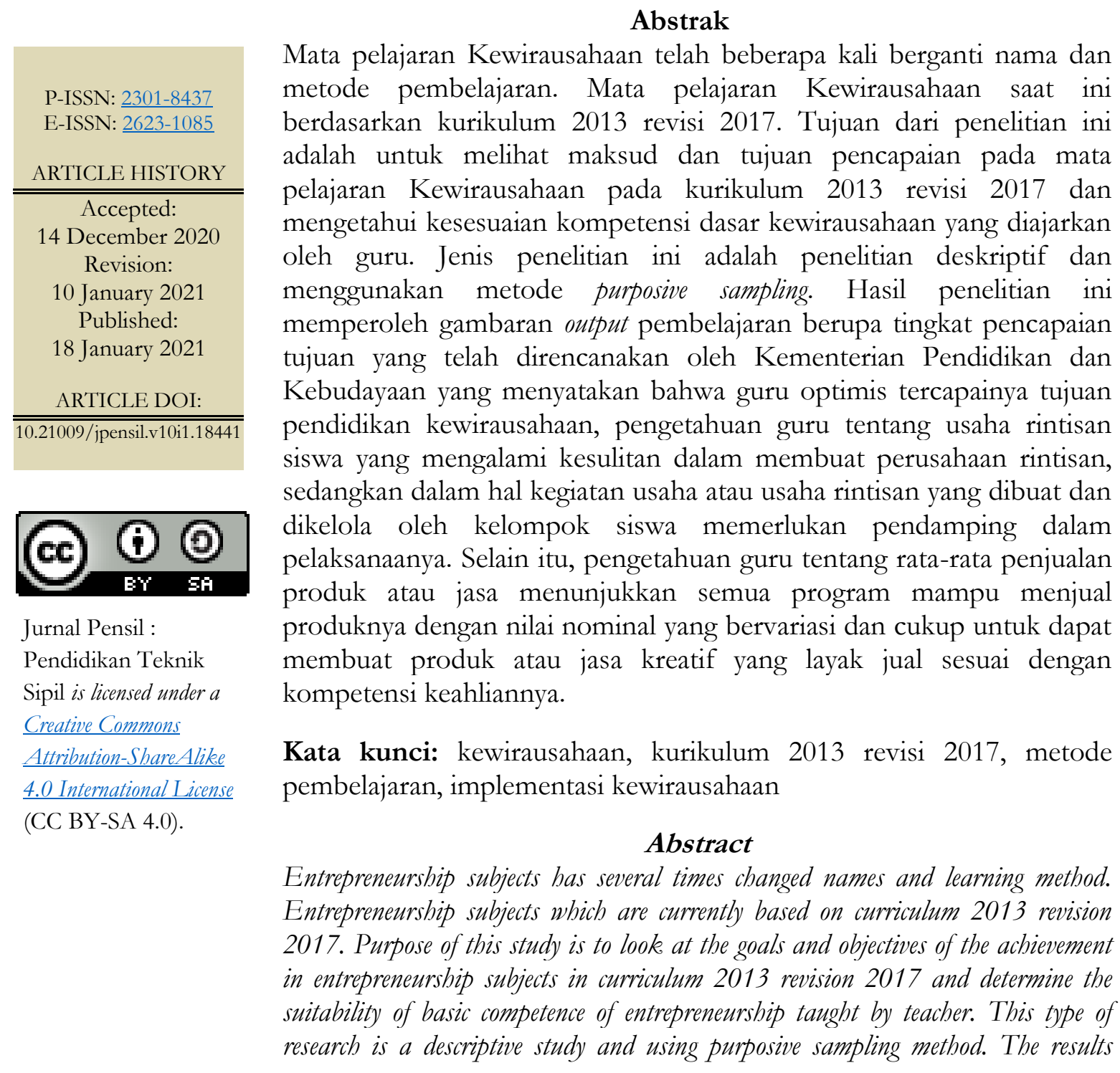


obtained a description of the learning output in the form of the level of achievement of the goals that have been planned by the Ministry of Education and Culture stating that teachers are optimistic about achieving entrepreneurial education goals, teacher's knowledge of student business start-up has difficulties in making business company start-up, while in terms of business activities or business start-up created and managed by student groups need assistance in its implementation. Also, the teacher's knowledge of the average sales of products or services shows all programs are able to selling their products with varying nominal values and are sufficient to be able to make selling-worthy creative products or services accordance with the competence of their expertise.

Keywords: entrepreneurship subject, curriculum 2013 revision 2017, learning method, implementation of entrepreneurship

\section{Pendahuluan}

Mata pelajaran Kewirausahaan terus dikembangkan dan disempurnakan. Hal tersebut ditandai dengan terjadinya tiga kali penyempurnaan kurikulum pendidikan kewirausahaan hingga saat ini, yaitu: a) Kurikulum 2004 revisi Kurikulum 2006, b) Kurikulum 2013, dan c) Kurikulum 2013 revisi 2017. Nama mata pelajaran untuk pendidikan kewirausahaan di SMK juga telah mengalami tiga kali perubahan, yaitu: a) Ekonomi dan Kewirausahaan, b) Prakarya dan Kewirausahaan (PKWu), dan c) saat ini Produk Kreatif dan Kewirausahaan (PKK). Tujuan pendidikan kewirausahaan melalui mata pelajaran Produk Kreatif dan Kewirausahaan (PKK) belum secara tegas dinyatakan di dalam kurikulum, sebagaimana pada mata pelajaran Prakarya dan Kewirausahaan yang secara tegas telah dinyatakan tujuannya, yaitu menumbuhkan semangat kewirausahaan pada siswa. Namun dari kompetensi-kompetensi dasar yang disusun, secara implisit tujuan pendidikannya adalah menghasilkan wirausahawan. Wirausahawan atau entrepreneur menurut Soegoto (2010) adalah seseorang yang memiliki jiwa dan kemampuan yang bersifat kreatif dan inovatif, mampu menciptakan sesuatu yang baru dan berbeda, mampu memulai usaha, mampu membuat sesuatu yang baru, mampu mencari peluang, berani mengambil risiko dan mampu mengembangkan ide dan meramu sumber daya. Dalam menghasilkan wirausahawan, pengajar kewirausahaan memiliki tantangan untuk menggali potensi peserta didik dan lingkungan sekitar untuk bisa membuka cakrawala dan keterampilan peserta didik dalam menghasilkan produk yang bernilai jual selama mereka menempuh pendidikan di SMK (Basri, Faiza, Nasir, \& Nasrun, 2019).

Tujuan pendidikan kewirausahaan pada kurikulum 2013 revisi 2017 untuk jenjang pendidikan SMK masih perlu dipertanyakan kesesuaiannya, mengingat Pendidikan SMK memiliki tiga tujuan, yaitu: a) Mampu bekerja secara terampil, b) Dapat melanjutkan studi, dan c) Mampu berwirausaha. Berdasarkan struktur Kurikulum 2013 revisi 2017 dapat dilihat bahwa jumlah tatap muka mata pelajaran PKK sebesar 10,45\% hingga 13\% dari jam tatap muka. Sedangkan untuk jumlah jam tatap muka kelompok mata pelajaran Produktif sebesar 50-55\%. Berdasarkan struktur tersebut tidak ada masalah apabila SMK didesain dengan lebih dari satu tujuan, termasuk tiga tujuan tersebut. Hal ini berdasarkan fakta banyak lulusan SMK yang mampu untuk melanjutkan studi ke jenjang pendidikan tinggi. Oleh sebab itu, tentu lulusan SMK juga mampu berwirausaha, mengingat lulusan SMK telah memiliki keterampilan kerja yang lebih baik daripada 
lulusan SMA. Berwirausaha menjadi jalan alternatif bagi lulusan SMK yang belum mendapatkan pekerjaan atau tidak melanjutkan studi ke jenjang pendidikan tinggi (Azis, Ninghardjanti, \& Susantiningrum, 2019).

Keterampilan kerja yang dimiliki dapat tentu dimanfaatkan untuk berwirausaha. Memang sepintas tidak ada masalah antara tujuan bekerja dan berwirausaha. Namun sebenarnya kedua hal tersebut menuntut mindset dan sikap yang berbeda, bahkan bertolak belakang. Mindset seorang pekerja yang baik dituntut dapat memahami bagaimana menyelesaikan pekerjaan sesuai dengan prosedur kerja yang telah diterapkan. Sedangkan mindset seorang wirausahawan dituntut dapat berpikir bagaimana menghasilkan pekerjaan yang menghasilkan keuntungan. Sependapat dengan Kusumandari (2013) bahwa seorang entrepreneur itu harus selalu mengetahui pengetahuan atau informasi baru (dimana orang banyak belum mengetahuinya) dan pengetahuan atau informasi baru tersebut dimanfaatkan untuk memperoleh keuntungan. Seorang pekerja harus berpikir linier berdasarkan standar tertentu, sedangkan seorang wirausahawan harus berpikir non linier atau berpikir kreatif-inovatif. Mindset calon wirausahawan adalah berani menghadapi ketidakpastian masa depan, sedangkan mindset pekerja adalah bagaimana mendapatkan kepastian penghasilan yang memiliki karir menjanjikan.

Sebagian besar lulusan SMK termasuk kelompok yang mampu bekerja secara terampil sesuai bidang keahlian. Hal ini dikuatkan oleh penelitian Winarno dkk. (2019) yang menjelaskan bahwa lulusan pendidikan SMK di Indonesia masih cenderung sebagai pekerja dan bukan calon wirausahawan. Ditambahkan dengan Subijanto (2012) bahwa lulusan SMK belum banyak yang mampu bekerja mandiri untuk mengimpelemtasikan dan mengembangkan keterampilannya (survive skills) dan di sisi lain masih rendahnya etos kerja lulusan SMK dalam hal enterpreneurial mindset. Hasil penelitian Winarno tersebut dapat diinterpretasikan dalam beberapa sudut pandang. Pertama, sebagian besar tujuan siswa memilih pendidikan SMK dan mungkin didukung oleh orang tua adalah untuk secepatnya memperoleh pekerjaan setelah lulus. Hal ini membentuk mindset siswa hingga lulus dan tidak berubah selama menempuh pendidikan di SMK. Kedua, sebagai surface warning bagi pendidikan kewirausahaan di SMK yang saat ini belum mampu merubah mindset siswa SMK atau dapat diartikan belum mampu merubah intensi dan karakter kewirausahaan. Ketiga, output pembelajaran pendidikan kewirausahaan di SMK belum mencukupi untuk menjadikan siswa sebagai calon wirausahawan. Keempat, kompetensi kerja yang dimiliki siswa belum mencukupi untuk mendukung penciptaan usaha bisnis yang nyata. Selain itu, belum ada data yang pasti tentang output dari pendidikan kewirausahaan di SMK saat ini.

\section{Metode Penelitian}

Jenis penelitian yang digunakan dalam penelitian ini adalah penelitian deskriptif yang berfokus pada outcome mata pelajaran kewirausahaan, sehingga termasuk kategori outcomes-based evaluation. Penentuan populasi dan sampel pada penelitian ini menggunkan metode purposive sampling. Sampel penelitian adalah SMK negeri dan swasta yang memiliki program keahlian jurusan bangunan dan subyek pada penelitian ini adalah guru pengampu mata pelajaran produk kreatif dan kewirausahaan di SMK. Teknik pengumpulan data menggunakan instrumen kuisioner yang telah tervalidasi dan teknik analisis data menggunakan statistik deskriptif kuantitatif.

\section{Hasil Penelitian dan Pembahasan}

Sampel penelitian ini sebanyak 10 SMK negeri maupun swasta, dengan rincian SMK Negeri 2 Depok, SMK Negeri 2 Yogyakarta, SMK Negeri 2 Pengasih, SMK Negeri 2 Wonosari, SMK Negeri 3 
Yogyakarta, SMK Negeri 1 Pajangan, SMK Negeri 1 Sedayu, SMK Negeri 1 Seyegan, SMK Muhammadiyah 3 Yogyakarta, dan SMK Muhammadiyah Pakem. Program keahlian terdiri atas 3 program keahlian yaitu: Desain Pemodelan dan Informasi Bangunan (DPIB), Bisnis Kontruksi dan Properti (BKP), dan Kontruksi Gedung Sanitasi dan Perawatan (KGSP). Jumlah responden sebanyak 19 orang guru pengampu mata pelajaran pendidikan kewirausahaan (2 orang responden didapatkan dari masing-masin SMK kecuali SMK Muhammadiyah Pakem yang hanya memiliki 1 orang responden). Sampel guru pengampu mata pelajaran pendidikan kewirausahaan terbanyak adalah dari Pendidikan Bisnis/Manajemen/Ekonomi sebanyak 11 orang $(57,9 \%)$, disusul dari pendidikan bukan Teknik dan Ekonomi sebanyak 6 orang $(31,6 \%)$, kombinasi Teknik dan Bisnis sebanyak 2 orang $(10,5 \%)$, dan tidak ada guru dari Pendidikan Teknik $(0 \%)$. Dalam penelitian ini, terdapat sebanyak $73,7 \%$ (7 SMK) yang memiliki jumlah siswa kurang dari 200 siswa, 10,5\% (1 SMK) yang memiliki siswa sekitar 600 s.d. 1000 siswa, 10,5\% (1 SMK) yang memiliki sekitar 200 s.d. 600 siswa, dan $5,3 \%$ (1 SMK) yang memiliki lebih dari 1000 siswa. Maka dapat disimpulkan sebagian besar program keahlian memiliki jumlah siswa kurang dari 200 siswa. Sedangkan jumlah kelas pada kompetensi keahlian tertentu dalam penelitian ini adalah $10 \operatorname{SMK}(52,6 \%)$ memiliki 3 kelas, sebanyak 7 SMK $(36,8 \%)$ memiliki 1 kelas, dan sebanyak 2 SMK (10,5\%) memiliki jumlah lebih dari 3 kelas. Jadi sebagian besar SMK memiliki 3 kelas dan 1 kelas, hanya 1 SMK yang memiliki lebih dari 3 kelas.

Dalam uraian ini berturut-turut diuraikan berkaitan dengan (1) tujuan pendidikan kewirausahaan untuk SMK bidang Keahlian Teknologi dan Rekayasa, (2) hasil pembelajaran mata pelajaran Produk Kreatif dan Kewirausahaan (PKK) di SMK bidang Keahlian Teknologi dan Rekayasa, (3) sasaran yang relevan untuk mencapai tujuan pendidikan kewirausahaan di SMK bidang Keahlian Teknologi dan Rekayasa, dan (4) sasaran yang perlu ditambahkan untuk pencapaian tujuan pendidikan kewirausahaan di SMK bidang Keahlian Teknologi dan Rekayasa.

Tujuan pendidikan kewirausahaan untuk SMK bidang Keahlian Teknologi dan Rekayasa berdasarkan data yang diperoleh mengenai pemahaman tujuan pendidikan kewirausahaan berdasarkan kurikulum 2013 revisi 2017 persepsi guru menyatakan sebanyak 31\% menyatakan mendidik siswa agar mampu membuat rintisan perusahaan bisnis siswa (student company), 36,8\% memiliki tujuan untuk mendidik siswa agar memiliki pengalaman dalam merintis usaha bisnis, dan $31 \%$ mendidik agar siswa mampu menciptakan produk atau jasa bernilai jual. Sementara pemahaman guru terkait pendidikan kewirausahaan yang sesuai dengan potensi program keahlian siswa didapatkan data sebagian besar guru sebanyak 53\% memiliki tujuan pendidikan untuk mendidik siswa agar mampu menciptakan produk atau jasa bernilai jual, sementara lainnya tersebar $16 \%$ dalam tujuan mendidik siswa agar mampu membuat rintisan perusahaan bisnis siswa, dan mendidik agar memiliki pengalaman dalam merintis usaha bisnis.

Berdasarkan data hasil pembelajaran mata pelajaran Produktif Kreatif dan Kewirausaan (PKK) tentang tingkat ketercapaian tujuan yang telah direncanakan sesuai dengan Kemendikbud, seluruh responden menyatakan optimis dalam ketercapaiaan tujuan pendidikan kewirausahaan berdasarkan kurikulum 2013 revisi 2017 dengan rincian sebesar 37\% responden menjawab sangat mungkin dicapai dan sebesar $63 \%$ responden menjawab dapat dicapai. Sehingga dapat dilihat bahwa tujuan yang telah dirumuskan oleh Kemendikbud untuk dapat dilaksanakan di sekolah dapat dicapai. Sementara berdasarkan data tentang pengetahuan guru mengenai rintisan perusahaan bisnis siswa (student company) yang berhasil dibuat oleh siswa atau kelompok siswa, didapatkan sebanyak 21\% 
guru menyatakan siswanya menghasilkan lebih dari 6 produk, $10 \%$ menghasilkan antara 5-6 produk, 15\% menghasilkan 3-4 produk, dan 47\% tidak memiliki produk sama sekali. Dari data tersebut dapat dilihat bahwa masih terdapat kesulitan dalam membuat rintisan perusahaan bisnis siswa (student company). Sedangkan dalam hal rintisan kegiatan atau usaha bisnis yang dibuat dan dikelola oleh kelompok siswa memperlihatkan lebih dari 6 buah membuat rintisan kegiatan atau usaha bisnis sebesar $11 \%$, antara 5-6 buah membuat rintisan kegiatan atau usaha bisnis sebesar 11\%, 3-4 buah membuat rintisan kegiatan atau usaha bisnis sebesar $21 \%, 1-2$ buah membuat rintisan kegiatan atau usaha bisnis sebesar $26 \%$, dan tidak memiliki atau belum mampu menghasilkan produk sebanyak 32\%. Dapat dilihat bahwa rintisan kegiatan bisnis siswa perlu pendampingan untuk meningkatkan keterlaksanaan.

Pengetahuan guru terhadap rerata penjualan produk atau jasa per kelompok siswa dalam penelitian ini menunjukkan bahwa ada sebanyak $20 \%$ guru berpendapat yang mampu menghasilkan lebih dari Rp.4.500.000,-, sedangkan $10 \%$ guru menyatakan menghasilkan antara Rp.3.000.000,- s/d Rp. 4.500.000, lalu 30\% guru menceritakan rerata penjualan di Rp. 1.500.000,- s/d Rp. 3.000.000,-, dan sisanya dikisaran Rp. 500.000,- s/d Rp.1.500.000, Dapat dilihat bahwa semua program keahlian mampu menjual produknya dengan nilai yang bervariasi. Data hasil penelitian tentang produk atau jasa kreatif layak jual menunjukkan bahwa mayoritas produk atau jasa dari hasil siswa atau kelompok siswa yang bernilai jual sebesar $60 \%$ menjawab lebih dari 6 orang/kelompok, 20\% menjawab berkisar 3-4 orang/kelompok, dan 11\% menjawab berkisar 5-6 orang/kelompok, dan $10 \%$ menjawab kurang dari 2 orang/kelompok. Hal ini menunjukkan bahwa kompetensi keahlian sudah cukup mampu membuat produk atau jasa kreatif yang layak jual. Jumlah produk kreatif yang dihasilkan menunjukkan bahwa mayoritas responden sebesar 53\% menjawab produk kreatif yang dihasilkan 12 produk, $26 \%$ menjawab produk yang dihasilkan berkisar 3-4 produk, 11\% menjawab lebih dari 6 produk, 5\% menjawab antara 5-6 produk 5\%, dan sisanya sebesar 5\% menjawab tidak memiliki produk. Hal ini menunjukkan bahwa jumlah produk kreatif yang dihasilkan sudah cukup mampu membuat produk atau jasa kreatif.

Pada aspek kesesuaian produk atau jasa yang dihasilkan siswa SMK, responden menjawab sangat sesuai, banyak kesesuaian, dan cukup sesuai dengan penyebaran persentase yang merata yaitu $32 \%$, sedangkan yang menjawab kurang sesuai hanya $5 \%$. Hal ini dapat dilihat aspek kesesuaian produk atau jasa yang dihasilkan siswa SMK sudah sesuai dengan kompetensi keahliannya. Sebagaimana dapat dilihat pada gambar di bawah ini.

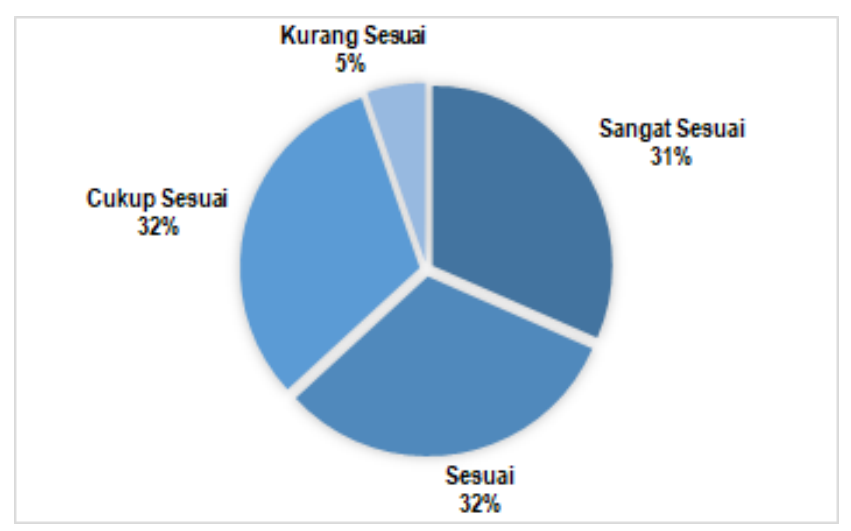


Gambar 1. Diagram Lingkaran Kesesuaiaan Rintisan Perusahaan Siswa dengan Kompetensi Keahlian

Mengenai kesesuaian rintisan menjawab produk penjualan atau usaha perusahaan siswa atau rintisan kegiatan bisnis yang dihasilkan dengan kompetensi bisnis, hasil penelitian menunjukkan bahwa sebesar $32 \%$ responden menjawab produk penjualan atau usaha bisnis yang dihasilkan dengan kompetensi keahlian sangat sesuai, sementara $37 \%$ responden menjawab produk penjualan atau usaha bisnis yang dihasilkan dengan kompetensi keahlian cukup sesuai, dan sebanyak $26 \%$ responden keahlian banyak kesesuiaannya. Hal ini dapat dikategorikan mengenai rintisan perusahaan siswa produk penjualan atau usaha bisnis yang dihasilkan dengan kompetensi keahlian sudah sesuai. Sebagaimana dapat dilihat pada gambar di bawah ini.

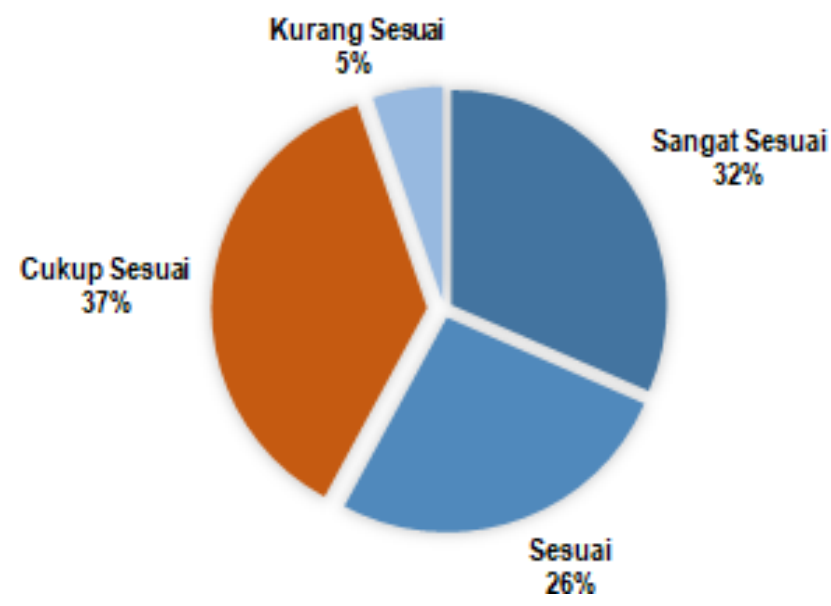

Gambar 2. Diagram Lingkaran Kesesuaiaan Rintisan Perusahaan Siswa dengan Kompetensi Keahlian

Gambaran data sasaran (objective) yang relevan untuk mencapai tujuan pendidikan kewirausahaan berdasarkan data yang diperoleh dukungan Kompetensi Dasar (KD) menurut Kemendikbud, dari 19 responden dengan 20 butir pertanyaan sehingga seharusnya diperoleh skor ideal tertinggi adalah $20 \times 5=100$ dan skor ideal terendah adalah $20 \times 1=20$. Rerata ideal (Mi) adalah $1 / 2(100+20)=60$, sedangkan standar deviasi ideal (SDi) adalah 1/6 (10020) $=13,33$.

Tabel 1. Kategorisasi Kriteria Sasaran yang Relevan untuk Mencapai Tujuan

\begin{tabular}{lll}
\hline $\begin{array}{l}\text { Rentang } \\
\text { Skor }\end{array}$ & Kategori & Frekuensi $\%$ \\
\end{tabular}

\begin{tabular}{llll}
\hline $\mathrm{X} \geq 73,3$ & $\begin{array}{l}\text { Sangat } \\
\text { mendukung }\end{array}$ & 11 & 57,89 \\
\hline & & & \\
\hline $\begin{array}{l}\text { Rentang } \\
\text { Skor }\end{array}$ & Kategori & Frekuensi & $\%$ \\
\hline $73,3>\mathrm{X} \geq$ & Mendukung & 7 & 36,84 \\
60 & & & \\
\hline $60>\mathrm{X} \geq$ & $\begin{array}{l}\text { Cukup } \\
\text { mendukung }\end{array}$ & 1 & 5,26 \\
\hline 46,7 & & & \\
\hline $46,7>\mathrm{X} \geq$ & $\begin{array}{l}\text { Kurang } \\
\text { mendukung }\end{array}$ & & 0,00 \\
\hline $\mathrm{X}<33,3$ & $\begin{array}{l}\text { Tidak } \\
\text { mendungkung }\end{array}$ & & 0,00 \\
\hline
\end{tabular}




\begin{tabular}{lll}
\hline Jumlah & 19 & 100 \\
\hline
\end{tabular}

Data yang diperoleh setelah proses pengambilan data di SMK D.I Yogyakarta menunjukkan skor tertinggi yang diperoleh adalah 100 dan skor terendah yang diperoleh adalah 53. Berdasarkan hasil perhitungan diperoleh nilai rata-rata sebesar 77, median sebesar 76, standar deviasi sebesar 13,723 dan varians sebesar 188.33. Sebagaimana dapat dilihat pada Tabel 2 berikut ini.

Tabel 2. Data Frekuensi Kesesuaiaan

Kompetensi Dasar (KD) dari

Kemendikbud untuk Mencapai Tujuan Mata Pelajaran

Kewirausahaan

\begin{tabular}{lll}
\hline 1 & $\mathrm{X} \geq 73,3$ & Sangat mendukung \\
\hline 2 & $73,3>\mathrm{X} \geq 60$ & Mendukung \\
\hline No. & Rentang Skor & Kategori \\
\hline 3 & $60>\mathrm{X} \geq 46,7$ & $\begin{array}{l}\text { Cukup } \\
\text { Mendukung }\end{array}$ \\
\hline 4 & $46,7>\mathrm{X} \geq 33,3$ & $\begin{array}{l}\text { Kurang } \\
\text { Mendukung }\end{array}$ \\
\hline 5 & $\mathrm{X}<33,3$ & Tidak Mendukung
\end{tabular}

Data frekuensi kesesuaian Kompetensi Dasar (KD) untuk mencapai tujuan mata pelajaran kewirausahaan pada tabel di atas menunjungkan rentang skor dan kategori yang dapat dinyatakan dalam bentuk diagram sebagai berikut:

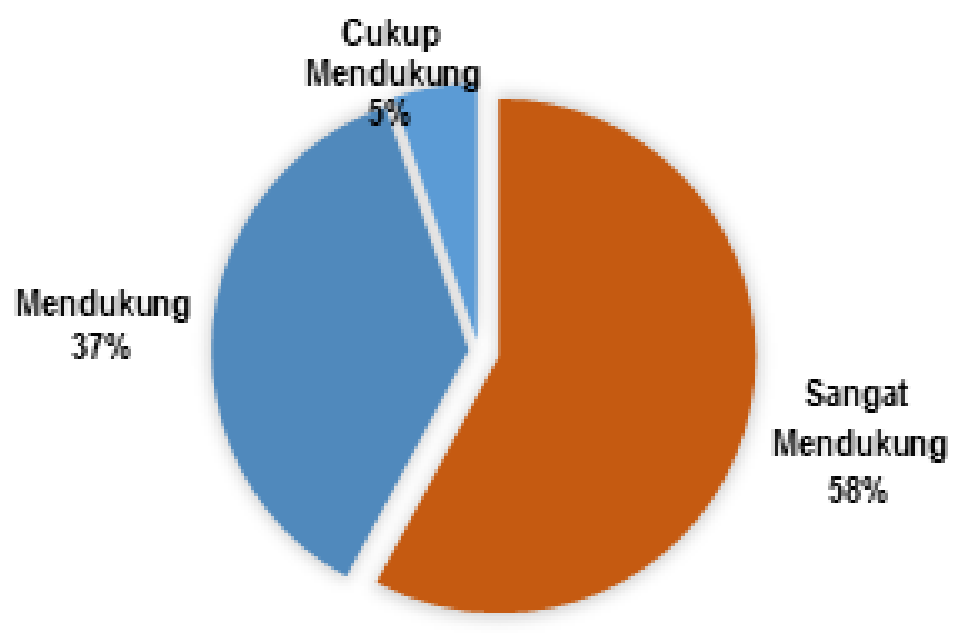

Gambar 3. Diagram Lingkaran Kesesuaiaan Kompetensi Dasar (KD) Dari Kemendikbud untuk Mencapai Tujuan Mata Pelajaran Kewirausahaan

Sebagian besar frekuensi atau sebanyak $58 \%$ memberikan pernyataan bahwa KD dari Kemendikbud sangat mendukung untuk mencapai tujuan mata pelajaran kewirausahaan. Sementara 37\% responden menyatakan mendukung dan hanya $5 \%$ yang menyatakan cukup mendukung. Dari uraian tersebut dapat dilihat bahwa KD dari Kemendikbud sudah mendukung tujuan pelajaran Kewirausahaan.

Sasaran atau Kompentensi Dasar (KD) yang perlu ditambahkan untuk pencapaian tujuan pendidikan 
kewirausahaan berdasarkan data yang diperoleh mengenai perlunya ditambahkan Kompetensi Dasar (KD) dalam pencapaiaan tujuan pendidikan kewirausahaan berdasarkan kurikulum 2013 revisi 2017 persepsi guru menyatakan sebanyak $47 \%$ guru menyatakan perlu untuk ditambahkan 1-2 KD, sedangkan $42 \%$ guru menyatakan tidak perlu ada penambahan $\mathrm{KD}$ terhadap $\mathrm{KD}$ yang telah ada. Dengan kata lain persepsi guru terhadap KD yang telah ada sudah cukup mengakomodir untuk menggapai tujuan pendidikan kewirausahaan. Sebagaimana dapat dilihat pada gambar berikut ini:

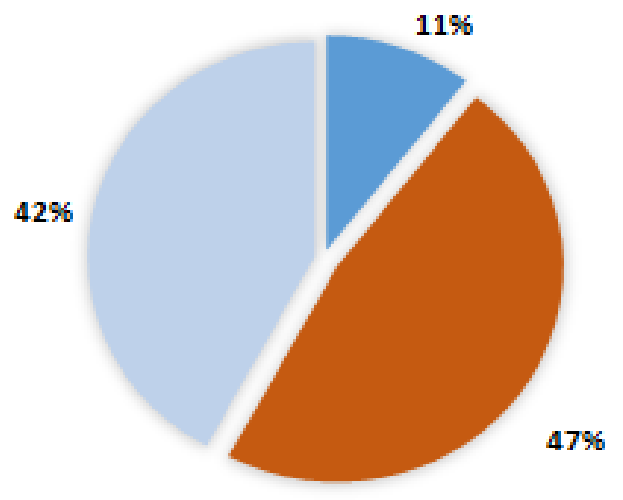

Gambar 4. Diagram Lingkaran Penambahan KD Untuk Mewujudkan Tujuan Pendidikan Kewirausahaan

Sementara itu, data berkaitan cukup sesuai dan sebanyak $11 \%$ sangat keterlaksanaan KD pada pembelajaran sesuai dan kurang sesuai. Hal ini kewirausahaan menunjukkan bahwa menunjukkan bahwa keterlaksanaan KD sebagian besar responden 63\% pada pembelajaran kewirausahaan sudah menyatakan $20 \mathrm{KD}$ yang telah ada telah sesuai dalam pembelajaran kewirausahaan. sesuai dalam keterlaksanaan pembelajaran Sebagaimana dapat dilihat pada gambar di kewirausahaan. Sementara responden bawah ini:

lainnya menyatakan sebanyak $16 \%$ sudah

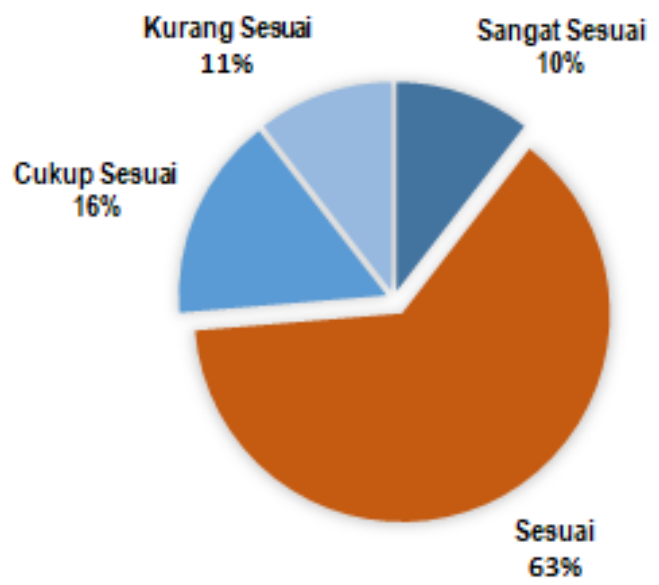

Gambar 5. Diagram Lingkaran Keterlaksanaan KD pada Pembelajaran Kewirausahaan 

Mengenai perlu tidaknya pelatihan kewirausahaan di luar mata pelajaran produktif kreatif dan kewirausahaan untuk

mewujudkan tujuan pendidikan kewirausahaan di SMK persepsi guru menyatakan mayoritas guru $73,7 \%$, sedangkan sisanya menjawab diperlukan dan cukup diperlukan. Tidak ada guru yang menjawab tidak diperlukannya pelatihan kewirausahaan. Sebagaimana dapat dilihat pada gambar berikut ini:

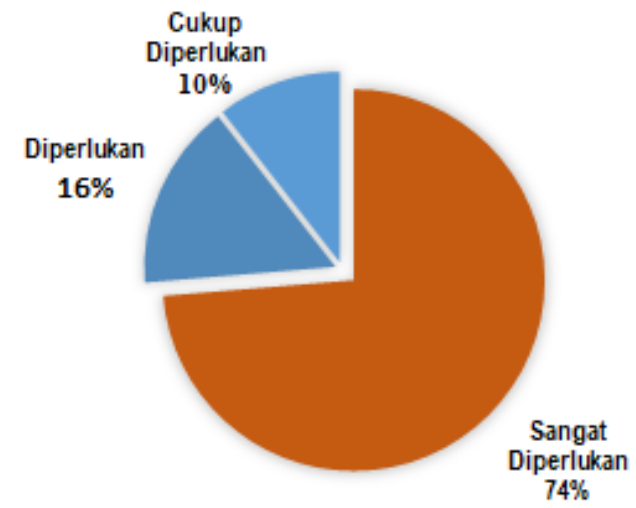

Gambar 6. Diagram Lingkaran Kebutuhan Pelatihan untuk Mewujudkan Tujuan Pendidikan Kewirausahaan

Hasil belajar produk kreatif dan kewirausahaan di SMK untuk merintis usaha bisnis baru menyatakan pendapat guru sebagai berikut. Sebanyak 15\% guru menyatakan sudah memadai bahwa hasil belajar produk kreatif dan kewirausahaan untuk merintis usaha bisnis baru, sementara responden lainnya menyatakan $47 \%$ guru menyatakan sudah cukup memadai, dan
31\% guru menyatakan kurang memadai.

Dari uraian tersebut dapat dilihat bahwa hasil belajar produk kreatif dan kewirausahaan di SMK sudah cukup memadai untuk dapat menjadikan modal dasar merintis usaha bisnis baru. Sebagaimana dapat dilihat pada gambar berikut ini:

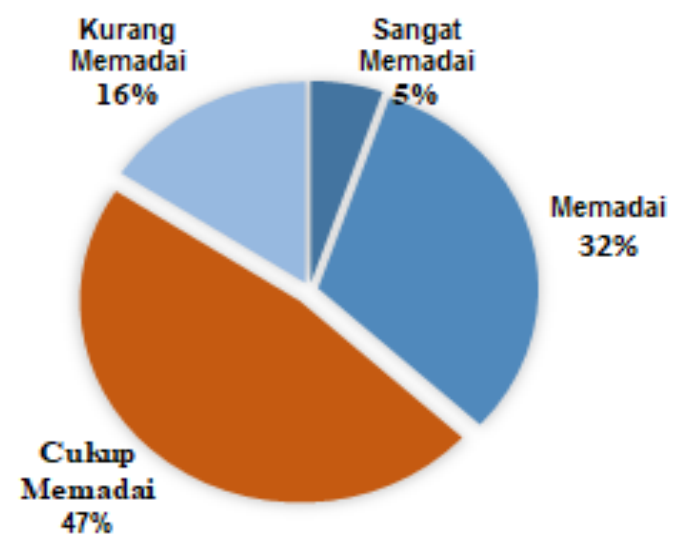

Gambar 7. Diagram Lingkaran Ketercapaiaan Hasil Belajar dalam Merintis Usaha Bisnis Baru 
Berdasarkan data yang diperoleh dapat dikaji secara lebih rinci mengenai pemahaman tujuan pendidikan kewirausahaan berdasarkan kurikulum

2013 revisi 2017 persepsi guru menyatakan sebanyak 31\% guru menyatakan mendidik siswa agar mampu membuat rintisan perusahan bisnis siswa (student company), sebanyak 36,8\% memiliki tujuan untuk mendidik siswa agar memiliki pengalaman dalam merintis usaha bisnis, dan sebanyak $31 \%$ mendidik agar siswa mampu menciptakan produk atau jasa bernilai jual. Sementara pemahaman guru terkait pendidikan kewirausahaan yang sesuai dengan potensi program keahlian siswa didapatkan data sebagian besar guru yaitu 53\% memiliki tujuan pendidikan untuk mendidik siswa agar mampu menciptakan produk atau jasa bernilai jual. Untuk detail menurut bidang keahlian yaitu guru bidang keahlian DPIB, sebagian besar memilih tujuan membuat rintisan perusahan bisnis siswa dan menciptakan produk atau jasa kreatif sebanyak masing-masing $42,9 \%$, lalu sebanyak 28,5\% guru memilih tujuan mampu melakukan kegiatan pokok dalam bisnis (produksi, pemasaran, penjualan), dan sebanyak 28,5\% guru memilih tujuan diluar Kemendikbud. Sedangkan untuk guru bidang keahlian Bisnis Kontruksi dan Properti (BKP), memilih tujuan menciptakan produk atau jasa kreatif sebanyak 50\% (2 orang guru), sebanyak $25 \%$ (1 orang guru) memilih mampu melakukan kegiatan pokok dalam bisnis (produksi, pemasaran, penjualan), dan sisanya $25 \%$ (1 orang guru) memilih tujuan di luar Kemendikbud. Sementara itu, guru bidang keahlian Kontruksi Gedung Sanitasi dan Perawatan (KGSP), sebagian besar $(62,5 \%)$ atau sebanyak 5 orang guru memilih tujuan menciptakan produk atau jasa kreatif, 25\% atau sebanyak 2 guru memilih tujuan diluar Kemendikbud, dan $12,5 \%$ atau sebanyak 1 guru memilih tujuan mampu melakukan kegiatan pokok dalam bisnis (produksi, pemasaran, penjualan).
Bila dilihat secara keseluruhan program keahlian, pendapat guru tentang tujuan pendidikan kewirausahaan di SMK bidang Keahlian Teknologi dan Rekayasa sangat bervariasi, berturut-turut dari yang terbanyak adalah mampu menciptakan produk atau jasa kreatif $(36,8 \%)$, di luar dari tujuan yang telah ditentukan kementerian (31,6\%), mampu melakukan kegiatan pokok dalam bisnis (produksi, pemasaran, penjualan) (26,3\%), mampu melakukan penjualan (selling) produk atau jasa kreatif karya siswa atau sekolah (5,3\%), dan tidak ada yang memilih mampu mendirikan perusahaan bisnis siswa (student company). Dari data tersebut dapat dilihat bahwa guru hanya menginginkan tujuan pendidikan kewirausahaan adalah menciptakan produk atau jasa kreatif dan melakukan kegiatan pokok dalam bisnis (produksi, pemasaran, penjualan).

Apabila dicocokkan mengenai definisi tujuan pendidikan kewirausahaan sebagai mana yang telah dijelaskan oleh Gautam \& Singh (2015) bahwa terdapat tiga konsep pendidikan kewirausahaan yaitu: a) enterprise education, b) entrepreneurship education, dan c) entrepreneurial education. Pada konsep pertama, enterprise education, tujuan pendidikan kewirausahaan adalah melatih dan menyiapkan kemampuan menciptakan perusahaan (venture) maka persepsi guru belum sampai pada tahapan ini. Sedangkan konsep kedua, entrepreneurship education, tujuan pendidikan kewirausahaan adalah mencetak individu yang mandiri dan pencari peluang bisni dan hal inilah yang paling dominan atau mayoritas dianut dan diajarkan di SMK. Sedangkan konsep ketiga tujuan pendidikan kewirausahaan, entrepreneurial education, menyiapkan individu agar memiliki kemampuan mengenali peluang bisnis, pengetahuan dan keterampilan (skill) untuk bertindak terhadap peluang tersebut. Hal ini juga tidak dijumpai dikarenakan keterbatasan sumber daya yang dimiliki, selain itu tingkatan ini harus memiliki pengalaman dan jam terbang sementara siswa SMK merupakan siswa yang baru belajar. 
Pendidikan kewirausahaan pada kurikulum 2013 revisi 2017 di SMK diaplikasikan dalam bentuk mata pelajaran Produk Kreatif dan Kewirausahaan (PKK). Tujuan kurikulum terdiri dari empat aspek kompetensi, yaitu (1) aspek kompetensi sikap spiritual, (2) sikap sosial, (3) pengetahuan, dan (4) keterampilan. Aspekaspek tersebut dicapai melalui proses pembelajaran intrakurikuler, kokurikuler, dan ekstrakurikuler. Dapat dijabarkan Kompetensi Dasar mata pelajaran Produk Kreatif dan Kewirausahaan (PKK) adalah sebagai berikut: 1) Memahami sikap dan perilaku wirausahawan, 2) Menganalisis peluang usaha dan menyusun peluang usaha produk barang atau jasa, 3) Memahami hak atas kekayaan intelektual, 4) Menganalisis konsep dan membuat desain dan kemasan produk, 5) Menganalisis proses kerja pembuatan produk dan kemasan, 6) Menguji prototype produk, 7) Membuat perencanaan produksi massal, 8) Membuat indikator keberhasilan produksi massal, 9) Melakukan produksi massal, 10) Melakukan perakitan produk massal, 11) Melakukan pengujian dan pemeriksaan produk, 12) Membuat media promosi dan melakukan pemasaran, 13) Membuat bagan perkembangan usaha, dan 14) Membuat laporan keuangan.

Berdasarkan data yang diperoleh terkait dukungan Kompetensi Dasar (KD) menurut Kemendikbud, dari 19 responden dengan 20 butir pertanyaan dapat dilihat sebagian besar frekuensi atau sebanyak $58 \%$ memberikan pernyataan bahwa KD dari Kemendikbud sangat mendukung untuk mencapai tujuan mata pelajaran Kewirausahaan. Sementara 37\% responden menyatakan mendukung dan hanya 5\% yang menyatakan cukup mendukung. Dari uraian tersebut dapat dilihat bahwa $\mathrm{KD}$ dari Kemendikbud sudah mendukung tujuan pelajaran Kewirausahaan. Ini artinya dengan jumlah 14 kompetensi dasar mata pelajaran Produk Kreatif dan Kewirausahaan (PKK) adalah sudah mengakomodir kompetensi dasar yang harus dimiliki seorang wirausaha, selain itu dalam pencapaianya 14 kompetensi dasar diajarkan oleh guru kewirausahaan terdapat kesulitan dalam penyampaiaan dan mempraktekan seperti pada KD pemahaman hak atas kekayaan intelektual yang masih kesulitan untuk dicontohkan dalam pembelajaran kewirausahaan.

Pendidikan kewirausahaan harus mengajarkan konsep dan keterampilan yang dapat diterapkan secara langsung untuk memulai, mengelola, dan menumbuhkan usaha bisnis atau kewirausahaan (Fayolle, 2007). KD yang telah dirancang dari Kemendikbud yang terdiri dari 14 kompetensi menurut persepsi guru sudah sangat mendukung untuk mencapai tujuan mata pelajaran Kewirausahaan. Hal ini dibuktikan dengan sebagian besar yaitu sebanyak 58\% memberikan pernyataan bahwa KD dari Kemendikbud sangat mendukung untuk mencapai tujuan mata pelajaran Kewirausahaan. Sementara 37\% responden menyatakan mendukung dan hanya 5\% yang menyatakan cukup mendukung. Sementara Konsep dan keterampilan menurut Lillevelli \& Taks (2017) menganjurkan diajarkannya kompetensi kewirausahaan, yang meliputi: 1) inisiatif, kreatif, risk taking, kemandirian, teamwork, dan kepemimpinan, 2) memahami proses bisnis, dan 3) pengembangan mindset kewirausahaan. Hal ini sebenarnya sudah terdapat ke dalam 14 aspek kompetensi dasar yang ada di KD kemendikbud, yaitu 1) inisiatif, kreatif, risk taking, kemandirian, teamwork, dan kepemimpinan, terdapat di $\mathrm{KD}$ ke dua yaitu menganalisis peluang usaha dan menyusun peluang usaha produk barang atau jasa, 2) memahami proses bisnis, tedapat di KD ke empat, lima, dan tujuh yaitu menganalisis konsep dan membuat desain dan kemasan produk, menganalisis proses kerja pembuatan produk dan kemasan dan membuat perencanaan produksi massal, dan 3) pengembangan mindset kewirausahaan, terdapat di KD terakhir membuat bagan perkembangan usaha dan membuat laporan keuangan. 
Konsep yang telah ada di kurikulum SMK di awal pembentukan dengan membagi mata pelajaran menjadi tiga rumpun, yaitu afektif, adaptif, dan produktif. Diharapkan dengan pembagian tersebut sesuai proporsional menjadikan siswa dibekali keahlian untuk dapat a) bekerja secara terampil, b) dapat melanjutkan studi, dan c) mampu berwirausaha.

Berdasarkaan data yang telah diperoleh terkait keterlaksanaan KD pada pembelajaran kewirausahaan menunjukkan bahwa sebagian besar responden 63\% menyatakan $20 \mathrm{KD}$ yang telah ada telah sesuai dalam keterlaksanaan pembelajaran kewirausahaan. Sementara responden lainnya menyatakan sebanyak $16 \%$ sudah cukup sesuai dan sebanyak $11 \%$ sangat sesuai dan kurang sesuai. Guna menunjang program tersebut perlunya kegiatan pelatihan kewirausahaan di luar mata pelajaran produktif kreatif dan kewirausahaan untuk mewujudkan tujuan pendidikan kewirausahaan di SMK, sebagaimana penjelaskan persepsi guru yang menyatakan mayoritas guru $73,7 \%$, terkait kebutuhan pelatihan untuk mewujudkan tujuan pendidikan kewirausahaan. Hasil belajar produk kreatif dan kewirausahaan di SMK untuk merintis usaha bisnis baru menyatakan pendapat guru bahwa sudah cukup memadai bahwaa kegiatan hasil belajar untuk bekal dalam merintis usaha baru. Pelatihan sangatlah penting baik bagi siswa dan guru untuk memberi wawasan terkait proses kewirausahaan yang sebenarnya, siswa SMK belum secara sadar dan perhatian terhadap kompetensi yang dimiliki yang telah diajarkan di sekolah.

Data dan fakta diatas apabila dilihat belum menunjukkan hasil yang nyata dikarenakan proses untuk membentuk calon wirausahawan dengan harapan terbentunknya rintisan perusahan bisnis siswa (student company) tidak serta merta terwujud begitu saja. Hal ini merupakan proses panjang dan tidak instan. Sebagaimana dijelaskan Gafar, Kasim, \&
Martin (2013) bahwa pendidikan kewirausahaan harus dimulai dengan siswa dan pendidik sebelum berfokus pada program, konten, dan metodologi pengajaran. Hasil program hanya dapat ditentukan sesuai dengan tangible (kapasitas sumber daya manusia), fasilitas belajar yang tidak berwujud (pengaturan akademik), dan lingkungan makro (pengaturan sosial). Berdasarkan pemaparan tersebut maka fokus dalam kegiatan pembelajaran di SMK untuk menunjang kewirausahaan secara garis besar dengan tiga pendekatan, yaitu pertama dari pendekatan teknis atau teknik (kompetensi yang berkaitan dengan keteknikan yang benar mewujudkan hasil yang berkualitas), kedua aspek bisnis (kompetensi yang berkaitan dengan ekonomis, efisiensi, dan manajerial) dan ketiga terkait kepribadian (kompetensi yang berkaitan dengan spiritual dan kepribadian).

\section{Simpulan}

Berdasarkan kegiatan penelitian yag telah dilaksanakan, kesimpulan yang dapat diambil adalah sebagai berikut: 1) Gambaran hasil pembelajaran mata pelajaran Produk Kreatif dan Kewirausahaan (PKK) di SMK Bidang Keahlian Teknologi dan Rekayasa sebagai berikut: tingkat ketercapaian tujuan yang telah direncanakan sesuai dengan Kemendikbud, seluruh responden menyatakan bahwa optimis ketercapaiaan tujuan pendididkan kewirausahaan berdasarkan kurikulum 2013 revisi 2017. Sementara pengetahuan guru mengenai rintisan perusahaan bisnis siswa (student company) yang berhasil dibuat oleh siswa atau kelompok siswa masih bervariasi tergantung kualitas pembelajaran dari masing-masing guru yang ada di sekolah, dan masih memiliki kesulitan dalam membuat rintisan perusahaan bisnis. Sedangkan dalam hal rintisan kegiatan atau usaha bisnis yang dibuat dan dikelola oleh kelompok siswa memperlihatkan bahwa rintisan kegiatan bisnis siswa perlu 
pendampingan untuk meningkatkan keterlaksanaan. Pengetahuan guru terhadap rerata penjualan produk atau jasa per kelompok siswa dalam penelitian ini menunjukkan bahwa semua program keahlian mampu menjual produknya dengan nominal yang bervariasi. Hasil penelitian tentang produk atau jasa kreatif layak jual menunjukkan bahwa mayoritas produk atau jasa dari hasil siswa atau kelompok siswa yang bernilai jual sudah cukup mampu membuat produk atau jasa kreatif yang layak jual. Jumlah produk kreatif yang dihasilkan menunjukkan jumlah produk kreatif yang dihasilkan sudah cukup mampu membuat produk atau jasa kreatif. Aspek kesesuaian produk atau jasa yang dihasilkan siswa SMK sudah sesuai dengan kompetensi keahliannya, 2) Sasaran (objective) yang relevan untuk pencapaian tujuan pendidikan kewirausahaan di SMK Bidang Keahlian Teknologi dan Rekayasa berdasarkan data yang diperoleh menjelaskan KD yang telah dirancang dari Kemendikbud yang terdiri dari 14 aspek menurut persepsi guru sudah sangat mendukung untuk mencapai tujuan mata pelajaran Kewirausahaan, 3) Tujuan pendidikan kewirausahaan yang sesuai untuk SMK Bidang Keahlian Teknologi dan Rekayasa yaitu konsep kedua (entrepreneurship education), tujuan pendidikan kewirausahaan adalah mencetak individu yang mandiri dan pencari peluang bisnis dan hal inilah yang paling dominan atau mayoritas dianut dan diajarkan di SMK.

Setelah dilaksanakan penelitian maka terdapat poin yang perlu diperhatikan untuk meningkatkan kualitas pembelajaran kewirausahaan diataranya, yaitu 1) Melihat data yang didapatkan bahwa guru hanya menginginkan tujuan pendidikan kewirausahaan pada tahap menciptakan produk atau jasa kreatif dan melakukan kegiatan pokok dalam bisnis (produksi, pemasaran, penjualan) padahal pada tujuan pencapaiaan dari program ini agar bisa membuat rintisan perusahan bisnis siswa (student company) maka diperlukan pelatihan bagi guru-guru untuk persamaan persepsi dan outcome yang dicapai. Selain itu juga untuk persamaan persepsi di forum MGMP yang ada di D.I Yogyakarta belum berjalan dengan baik, hal ini berbeda dengan provinsi lain, 2) Pembentukan rintisan perusahan bisnis siswa (student company) tidak serta merta terwujud begitu saja. Pendidikan kewirausahaan harus dimulai dengan siswa dan pendidik sebelum berfokus pada program, konten, dan metodologi pengajaran. Hasil program hanya dapat ditentukan sesuai dengan tangible (kapasitas sumber daya manusia), fasilitas belajar yang tidak berwujud (pengaturan akademik), dan lingkungan makro (pengaturan sosial).

\section{Daftar Pustaka}

Azis, F., Ninghardjanti, P., \& Susantiningrum. (2019). Pengaruh Keterampilan Kewirausahaan Dan Persepsi Peluang Kerja Terhadap Minat Berwirausaha Siswa SMK Negeri 1 Banyudono. Jurnal Informasi dan Komunikasi Administrasi Perkantoran Vol. 3(4), 87-96.

Basri, I., Faiza, D., Nasir, M., \& Nasrun. (2019). Implementasi Pembelajaran Berbasis Produk Dalam Rangka Menyiapkan Lulusan SMK Menjadi Wirausahawan Muda. Jurnal Inovasi Vokasional dan Teknologi Vol. 19(1), 43-52.

Fayolle, A. (2007). Handbook of Research in Entrepreneurship Education Vol. 1. Chellenham \& Massachusetts: Edward Elgar.

Gafar, M., Kasim, R., \& Martin, D. (2013). Entrepreneurial Idea Development to Business Start-Up: Teaching Methodological Approach. Journal of Research \& Method in Education, Vol. 1 (4), 46-55.

Gautam, M., \& Singh, S. (2015). Entrepreneurship Education: Concepts, Characteristics and 
Implications for Teacher Education. SPIJE 5(1),, 21-35.

Kusumandari, R. B. (2013). Model Pendidikan Kewirausahaan Dalam Mengembangkan Jiwa Wirausaha Siswa SMK Unggulan. Journal of Economics and Policy 6(1), 64-79.

Lillevelli, U., \& Taks, M. (2017). Competence Models as Tool for Conseptualizing Systematic Process of Entrepreneurship Competence Development. Hindawi Educational Research International.

Soegoto, E. (2010). Entrepreneurship: Menjadi Pebisnis Ulung Panduan bagi Pengusaha, Calon Pengusaba, Mahasiswa dan
Kalangan Dunia Usaba. Jakarta: Gramedia.

Subijanto. (2012). Analisis Pendidikan Kewirausahaan di Sekolah Menengah Kejuruan. Jurnal Pendidikan dan Kebudayaan Vol. 18(2), 163-173.

Winarno, A., Wijiyanti, T., Agustina Y., Churiyah, M., \& Basuki, A. (2019). Integration Of Vocational School and Small-Medium Enterprise (SME) Learning: an Effort of Elevating Entrepreneurship Spirit Based on Strength and Weakness in East Java. Academy of Entrepreneurship Journal 25(1), 1-11. 